\title{
Need of Biopesticides Triumph over Chemical Pesticides
}

\author{
Lovepreet Singh and Vipul Kumar* \\ Department of Plant Pathology, School of Agriculture, Lovely Professional University, \\ Phagwara, Punjab, India \\ *Corresponding author
}

\section{A B S T R A C T}

\begin{tabular}{l}
\hline Ke y w or d s \\
Biopesticides, \\
Pesticides, \\
Entomopathogenic \\
fungi, \\
Entomopathogenic \\
bacteria, Biocontrol \\
agents \\
\hline Article Info \\
\hline $\begin{array}{l}\text { Accepted: } \\
\text { 04 December } 2020 \\
\text { Available Online: } \\
\text { 10 January } 2021\end{array}$ \\
\hline
\end{tabular}

Biopesticides serve as second-hand biocontrol agents against harmful microbial growth and supplement as organic pesticides in several agricultural systems. In the production of alternative controls for synthetic insecticides to kill insect pests, biotechnology may also condone them. Bacterial and fungal agents such as Ampelomyces quisqualis and Trichoderma spp., (a control agent for grape powdery mildew) and Bacillus subtilis (used to control plant pathogens) are continually used as second-hand biopesticides. Agile properties of these biocontrol agents either directly affect the pathogen (e.g., Contans) or create a regulated compound during fermentation (e.g., Sonata). The rationale for invariable take-away meals has led traditional agriculture to be heavily dependent on chemicals. Extending the bond between the clientele and the charge on board has driven farmers to pursue new environmentally sustainable approaches to supplement, or at least complement, existing chemical-based activities. The interest in biopesticides has arisen as a potential alternative to traditional pesticides. The effectiveness of biopesticide bacteria such as, Pseudomonas aureofaciens, Bacillus circulans, Agrobacterium radiobacter, B. pumilus and fungi such as Fusarium oxysporum, Ampelomyces quisqualis, Gliocladium virens, Pythium oligandrum and T. harzianum has been used by several countries for sustainable enhancement of crop yield.

\section{Introduction}

In India, the use of chemical pesticides began in 1948, while development began in 1952 with the production of DDT \& BHC near Calcutta. Surprisingly, pesticide intake in India during the 1954-2000 period ranged from 433 Metric tonnes to 47000 Metric tonnes. Andhra Pradesh is first (23 percent) in terms of state wise consumption of pesticides, followed by Punjab \& Maharashtra. (Source:
Central Insecticides Board \& Registration Committee, Ministry of Agriculture, 2008). India is currently 12th in the world and the largest producer of pesticides in Asia. Despite their many benefits, due to the uncontrolled and indiscriminate application of pesticides. The first case of lethal death attack was observed in Kerala in 1958, while consuming poisoned wheat flour with parathion, considering its enormous advantages, many serious problems have been reported here. In 
developing countries, 25 million farm workers suffer from an outbreak of poisoning every year. In addition to these concerning statistics, even small concentration triggers significant health issues such as immune deficiency, hormone disturbance, reduced intelligence, reproductive defects, and cancer along with pesticide consumption. Just 0.1 percent of the distribution of pesticides targets the pest, 99.9 percent stay in the atmosphere and seep out. The goal of this article is to illustrate the current global situation, including the demand, supply and utility of these chemical pesticides.

\section{Pesticide production and consumption in India}

In India, pesticide use started in 1948 when Dichloro diphenyl trichloroethane (DDT) was imported to control malaria and benzene hexachloride (BHC) for control of pest of Orthoptera. India began production of pesticides in 1952 with a production facility for DDT and BHC now Hexa chloro cyclohexane $(\mathrm{HCH})$. In 1958, over 5000 metric tonnes of pesticides were developed by India. Currently, a total of 215 pesticides in India are licensed for production and use. Annual pesticide production growth was 14.9 percent between 2001 and 2005.fungicides (18\%), weedicides (23\%), Insecticides (55 $\%$ ), fumigants (2percent) and the other rodenticides (1-2\%), are the percentage products for the distribution of different types of pesticides. (Source: www.cibrc.nic.in,2008). The above figure clearly shows that, compared to other forms of pesticides, the production of insecticides is high in India. Recently, it has been observed in India that pesticide consumption is increasing. Intensive agricultural systems, which have mainly been triggered by improvements in cropping patterns and practices, are gradually becoming a great contribution (Shetty et al., 2008).

\section{Pesticide use for disease control}

At the beginning of agriculture, plant diseases played a crucial role and contributed to $13 \%$ $20 \%$ losses in crop production worldwide (Anon., 1993). Several plant pathogenic fungi, such as Phytophthora, Fusarium, Pythium, Rhizoctonia, Sclerotinia and Botrytis have been widely distributed over the last few years, causing tremendous losses in important economic crops. Furthermore, fruits stored are also affected by fungal infection. Chemical regulation of significant diseases is inefficient, but it contributes to the production of resistant pathogenic strains and pollutes the environment as a short-term step. The extensive use of agrochemicals in agriculture has resulted in increasing environmental and public health issues in recent years. Biological regulation, on the other hand, it is chemicalfree and a perfect solution for inadequate plant disease control (Chet et al., 1997)

\section{Pesticides in India}

Fungicide: Fungicides have been used to protect plants against fungal diseases for more than 200 years (Brent and Hollomon, 2007). The use of fungicides in India is very low relative to developed countries. The total use of fungicides is lower compared to other pesticides. In 2009, the use of fungicides was 8300 metric tonnes compared to6045 metric tonnes of herbicides and 27000 metric tonnes of insecticides. Apart from conventional compounds like sulphur, dithiocarbamates, copper-based, etc., numerous site-specific groups of the fungicide like oxathiins, benzimidazoles, phenylamides, triazoles and other sterol biosynthesis inhibitors, strobilurins and other newly developed compounds are used to control indifferent destructive crop diseases. In India, the maximum intake of fungicides is around 75 percent of the total fungicides used on fruits (Thind, 2002). 311 compounds which are 
licensed and used as a fungicide for the prevention of different fungal diseases (Milne, 2004). Fungicides have been shown to cause acute toxicity, and others to cause chronic toxicity. (Goldman, 2008)

Insecticide: Insecticide used for insects \& pest management. The introduction of modern insecticides mostly affecting the nervous system of the insect pest. Botanical preparations seem to be the first substance and insecticide used in ancient times. For example, Dalmatian pyrethrum flowers contain up to 1.5 percent of the pyrethrin (effective insecticidal toxin) used as an insecticide in ancient China and then in Persia (Davies et al., 2007). The era of DDT in plant defense has been replaced by the era of extensive use of organophosphates (profenofos, dichlorvos, cyanophos, etc.) and carbamates (aldicarb, carbofuran, carbaryl, etc.). While carbamates and organophosphates are harmful to the environment, these insecticides are still among the most prominent groups of insecticides $(19 \%$ of the total world consumption) and are used to control pest insects (Casida and Durkin 2013).

Herbicide: Several weed control strategies have been illustrated, such as physical, cultural, biological, technological and chemical measures (Qasem, 1992) using single or combined methods for every effective weed control measure (Singh et al., 2006; Qasem, 2003). Herbicides are the organic or inorganic chemicals which inhibiting or destroying weeds, they donot harm crops only attack selectively to the weeds or unwanted species of the plants (California Weed Meeting, 1985). Herbicides account for 44 percent of the world's pesticide markets. Although 57 percent of these are for the USA. In 1925, the first application of sodium chlorate was done directly to soil to destroy weeds (Kiely et al., 2004).

\section{Present scenario of pesticides}

In India, the consumption of pesticides is increasing day by day. Cotton (37\%) consumed large amount pesticide, followed by rice $(21 \%)$. Andhra Pradesh (23 percent), led by Punjab \& Maharashtra, is the largest pesticide consuming state. Almost 150 pesticides are currently licensed in India with legal applications. Currently, India is the largest producer of pesticides in Asia and ranks 12th for pesticide applications in the world (Bhardwaj1 and (2013) Sharma).

\section{Classification of Pesticide on the basis of their target organisms:}

\begin{tabular}{|c|c|c|}
\hline Serial no. & Chemical Pesticides & Target Organisms \\
\hline $\mathbf{i}$ & Fungicides & Fungi \\
\hline $\mathbf{i i}$ & Insecticides & Insects \\
\hline $\mathbf{i i}$ & Viricides & Virus \\
\hline $\mathbf{i v}$ & Antibiotics & Bacteria \\
\hline $\mathbf{v}$ & Desiccants & Dryupplants or animals \\
\hline $\mathbf{v i}$ & Acaricides & Mites, spiders \\
\hline $\mathbf{v i i}$ & Weedicides & Weeds and Herbs \\
\hline $\mathbf{v i i i}$ & Algicides & Algae \\
\hline $\mathbf{i x}$ & Molluscicides & Slugs and Snails \\
\hline $\mathbf{x}$ & Nematicides & Nematodes \\
\hline $\mathbf{x i}$ & Piscicides & Fish and other aquatics animals \\
\hline $\mathbf{x i i}$ & Rodenticides & Rat, Mouse and other Rodents etc. \\
\hline
\end{tabular}




\section{New substitutes to chemical pesticides}

Chemical control of disease vectors has been remarkably successful, but it is important to reduce the dependency on chemical measures and to implement new methods of biological control and environmental protection if the aim is sustainable development. Lately, several new pesticide substitutes have appeared:

\section{Biopesticides in India}

Organic pesticides account for just 2.89 percent of overall pesticide demand in India (as of 2005) and are expected to increase dramatically in the coming years. Just 12 types of biopesticides have been registered in India so far under the Insecticide Act of 1968.Bacillus thuringiensis, Nuclear polyhedrosis viruses and Trichoderma sp. are the main pesticides used in India (Source: Environmental Microbiology \& Biotechnology, Central University of Punjab, Bathinda). Whereas, for use as chemical pesticides, more than 190 synthetics are registered.

Botanical pesticides are obtained from plant sources, such as onion extract, eucalyptus globules, pyrethrum daisy extract, neem azadirachtin, etc.

Microbial insecticides: made up of living microorganisms (viruses, bacteria, fungi, protozoa or nematodes). The biological control agents, e.g., Pseudomonas sp., Trichoderma harzianum and Bacillus thuringiensis have made the greatest development.

\section{Entomopathogenic nematodes}

There are two genera of entomopathogenic nematodes, such as Heterorhabditis and Steinernema, which have been successfully used in modern biological control. (Georgis \& Gaugler, 2005a) (Grewal et al., 1991)

Entomopathogenic virus: Viruses currently used in agriculture belong to two genera of the family Baculoviridae, namely Granulovirus (GV) and Nucleopolyhedrovirus (NPV). Baculoviruses, spray-administered, infect mosquitoes and other arthropods and do not harm vertebrates. A virus infected insect larva will produce billions of replicated viruses inside its body (Bonning and Nusawardani, 2007) suggested that the target pest insects of trees, orchards, horticultural, ornamental, dried fruit and nuts, as well as grain crops like soybeans (Kabaluk and Gazdik 2005). As of 2005, 14 licensed commercial baculovirus products in various countries are included in the OECD microbial pesticide directory; 9 products under GV and 5 products under NPV.

\section{Entomopathogenic bacteria}

Hurst and others (2010) have described a new genus of entomopathogenic bacterium and have suggested the name Yersinia entomophaga (MH96 strain). In New Zealand, a grass grub, Costelytra zealandica (Order-Coleoptera), has been found to infect it. Within 3 to 5 days of exposure, a number of lepidoptera and Coleoptera species is effectively killed by the bacterium. A patent lawsuit was lodged delineating the use of the bacterium as biopesticides and its derivatives (Glare and Hurst, 2010).

\section{Entomopathogenic fungi}

The Directory of the OECD lists 5 species of fungi that are present in the market. They are: Metarhizium anisopliae, Beauveria brongniartii, B. bassiana, Paecilomycetes fumosoroseus and Verticillium lecanii, both of the first genus, $M$. anisopliae and B. bassiana make up $35 \%$ and $39 \%$ of the total fungi 
registered among member countries, respectively (Kabaluk and Gazdik, 2005). It was proposed by Meyling and Eilenberg (2007) that only insect hosts on the ground are associated with B. Bassiana, while $M$. Anisopliae are associated in temperate agroecosystems with hosts, exclusively on or below the soil surface. Thungrabeab and Tongma (2007) have confirmed that these two fungal species, including common natural enemies such as Chrysopids and Coccinellids, found in Thailand, are generally not pathogenic to non-target organisms.

\section{Herbal pesticides}

Fly-ash-based herbal pesticides derived from waste content from thermal plants have developed to be a useful insecticide against many pests that infest the vegetables, maize and other crops. It is developed as a potential dust- 8 insecticide as well as an active carrier in various insecticide formulations, such as dust, wet table powder, and granules.

\section{Microbial antagonist}

Several agricultural microorganisms have been reported to have inability to biocontrol plant pathogens but they are used for indifferent purposes such as, control of plant diseases, weeds, insect pests, promotion of plant growth and organic material degradation (Vessey, 2003). There have been some antagonists against the phytopathogenic fungi such as (Pal and Gardener, 2006).

\begin{tabular}{|c|c|c|}
\hline S. No & Phytopathogenic fungi & Antagonists \\
\hline $\mathbf{1}$ & Agrobacterium tumefaciens & Agrobacterium radiobacter \\
\hline $\mathbf{2}$ & Gaeumannomyces sp. and Pythium spp. & Pseudomonas fluorescens \\
\hline $\mathbf{3}$ & $\begin{array}{c}\text { Phytophthoramedicaginis and } P . \\
\text { aphanidermatum }\end{array}$ & Bacillus cereus \\
\hline $\mathbf{4}$ & $\begin{array}{c}\text { Rhizoctonia solani, Fusariumoxysporum, } \\
\text { Aspergillus niger }\end{array}$ & Trichoderma viride \\
& Fusariumoxysporum & \\
\hline $\mathbf{5}$ & Aspergillus sp. & B. amyloliquefaciens \\
\hline $\mathbf{6}$ & Rhizoctonia solani and Pyicularia oryzae & Burkolderia cepacia \\
\hline $\mathbf{7}$ & Rhizoctonia solani & Saccharomyces sp. \\
\hline $\mathbf{8}$ & Gliocadium virens \\
\hline $\mathbf{9}$ & Fusarium oxysporum, Alternaria sp. & Trichoderma harzianum \\
\hline
\end{tabular}

\section{Fungal biopesticide}

Trichoderma: In distribution, Trichoderma is diverse and seldom present in all kinds of soil, manure and rotting plant materials (Alexander, 1961). In Germany, Trichoderma was first suggested by as a genus (Persoon 1794). It was first isolated from Madras by Thakur and Norris in India in 1928. The potential value of the Trichoderma genus as bioagents was first reported in 1932 by Weindling.
It was confirmed after several studies that Trichoderma spp. are kill most of the fungi that are capable of producing antibiotics that affect other microbes and of acting as biocontrol microbes (Weindling, 1934).

The antagonists of phytopathogenic fungi were used to control plant diseases and $90 \%$ of those applications were carried out with indifferent strains of Trichoderma (Monte, 2001). The positive benefits of Trichoderma as biocontrol agents (BCAs) are due to various beneficial characteristics such as 
antagonistic ability, rhizosphere competence, lytic enzyme, antibiotic, and toxin production capacity. These biological control activities are carried out either directly by antagonism of soil-borne pathogens or indirectly by a response to tolerance mediated by plants. In any ecosystem with a high population density, these properties have made Trichoderma a widespread genus (Misran and Prasad, 2003).

\section{Bacterial biopesticides}

The Pseudomonas is motile, non-sporulating rod shapes with gramme negative bacterium and 58-69 percent GC material, containing one or more flagella (Palleroni, 2008). The biocontrol capability of the fluorescent pyoverdine siderophore (s) developed by all Pseudomonas species, especially, P. putida, $P$. syringae, $P$. fluorescens, and $P$. aeruginosa (Bossis et al., 2000). Pseudomonas fluorescens is found in soil and in plant roots (Kiely et al., 2006).

Pseudomonas strains with the ability to manufacture the 2,4-dacetylphloroglucinol (Phl) antifungal metabolite can be isolated at high frequencies from tobacco suppressive soils to black root rot and take-all wheat disease. Recently, $\mathrm{Phl}$ is produced on the roots of wheat grown in soils that suppress take-all disease (Raaijmakers et al., 2002).

\section{Necessity of biocontrol agents}

The pesticide comprises biological compounds originates from bacteria, viruses, fungus, plant or animal, pheromones are classified as a biopesticide. Only targeted insects or closely unrelated pests are extremely specific and do not harm humans or beneficial animals, while non-target creatures, including rodents and parasites, and humans are likely to be harmed by chemical pesticides, which are wide-ranging.

Environmental friendliness and rapid biodegradability are the striking characteristics of biopesticides, resulting in lower residues of pesticides and essentially eliminating contamination problems associated with chemical pesticides. In contrast, the use of biopesticides, as part of the Integrated Pest Management (IPM) programme, will greatly reduce the use of traditional (chemical) pesticides, thereby achieving about the same crop yield. The efficient use of biopesticides, in particular by end-users, must be accepted as a great ideal for the management of pest control. Biopesticides also have an advantage over chemical pesticides in terms of manufacturing and commercialization, such as low research investment, a higher rate of crop development and a versatile registration process.

\section{Indian crop protection chemical usage pattern}

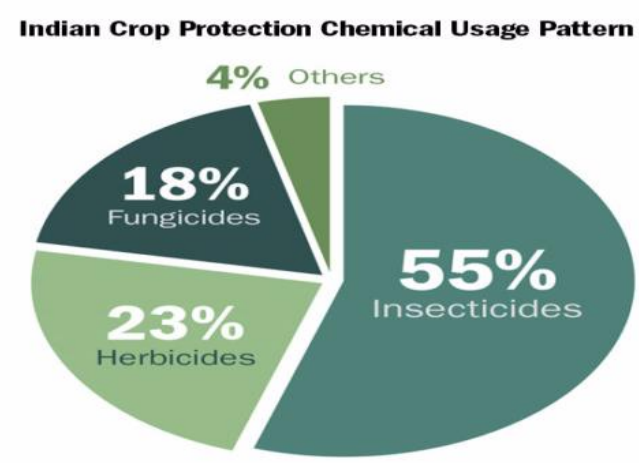

Source:www.agribusinessglobal.com(2017) 


\section{Present scenario of biopesticide}

\begin{tabular}{|c|c|c|}
\hline Features & Biopesticides & Pesticides \\
\hline Nature & Bio-degradable in nature \& eco-friendly & Cause environmental pollution \\
\hline $\begin{array}{c}\text { Toxic effect } \\
\text { Bumber of spraying }\end{array}$ & $\begin{array}{c}\text { Used in very small amounts, including 4 or 5 } \\
\text { sprays per season per plant. }\end{array}$ & $\begin{array}{c}\text { Spray in large amounts, such as } \\
\text { 10-20 sprays per season per crop. }\end{array}$ \\
\hline $\begin{array}{c}\text { Impact on the } \\
\text { fertility of soil }\end{array}$ & $\begin{array}{c}\text { the fertility of the soil is positively affected. } \\
\text { Action }\end{array}$ & $\begin{array}{c}\text { Thertility of the soil is } \\
\text { adversely affected. }\end{array}$ \\
\hline Chlorophyll Effect & $\begin{array}{c}\text { Insecticides, fungicides, viricides, } \\
\text { insect repellants. }\end{array}$ & $\begin{array}{c}\text { Physiological hazard and } \\
\text { chemical imbalances' } \\
\text { Damage the proteins and } \\
\text { chlorophyll in plants }\end{array}$ \\
\hline
\end{tabular}

The new strategy for disease control relies on synthetic chemical pesticides that have harmful effects on beneficial species, residues of pesticides in food, feed and fodder, and also pollute the environment. While intensive agriculture provides adequate grain food, it is heavily involved in the climate. Owing to the problems of developing resistance in pests and the removal of such goods for regulatory or commercial purposes, fewer chemical pesticides are available on the market. Out the 215 pesticides licensed for use in India, 39 were banned or removed (as of September 2008) from the market. Increased public concern about the possible adverse environmental effects associated with the use of synthetic plant protection and agrochemical processing has prompted the search for biological pest control products and technologies.

\section{Drawbacks of the biopesticides over conventional pesticides}

For biopesticides, some drawbacks are there, since they are highly target specific, farmers will also need training to use different types of products of bio pesticides effectively to combat against different types of disease pathogens and insect pests. Other limitations of biopesticides include preserving self-life (microbial viability) during storage, compatibility with chemical pesticides and innovations in distribution, in addition to implementation.

\section{Future prospectus and challenges}

Novel source identification: Eg. Nano silica as a prospective biopesticide agent. Biofumigation: consortium of two or more microbial.

Innovative formulations: to assist farmers in the development of residue-free products based on the most major crops and growing stages in terms of the risk of pesticide residues in final foods and to pick suitable biopesticides according to their intrinsic technical characteristics.

Identification of effective biopesticides in terms of shelf life and effectiveness against pests and scale-up the production.

Intensify the research on some specific aspects of the registration of new bioproducts requested.

Creative approach to the public-private sector,

Fostering investment in bio pesticide companies. 
In conclusion a complete global look at the scenario indicates that the industry-based biopesticides are still in an insecure position compared to the chemicals that regulate agriculture. Biopesticides slowly replace the chemical pesticides. We may conclude that, while biopesticides show great promise, they have not achieved the desired stage to displace the dominance of chemicals. In this section, the global scenario of biopesticides high lights the usage, current demand, remedies and restrictions. Continued regulatory measures are expected to promote better, cost-effective disease and pest management. This, in turn, would support the production of new products and GMOs (Genetically modified organisms). Because of improved farmers' understanding of the customer benefit equation and market demand, the adoption of biopesticides is bound to increase. These variables will be brought paradigm change in the attitude and also brought by cost-effective alternatives. Biopesticides are here to remain as "lifeextenders" or "standalone" entities in commercial agriculture which is an integral part of crop production.

\section{References}

Bonning, B.C. and Nusawardani, T. 2007. Introduction to the use of Baculoviruses as biological insecticides. In: Baculovirus and insect cell expression protocols. Methods in Molecular Biology 388: 359-366. ISSN: 1064-3745.

Bossis, E., Lemanceau, P., Latour, X. and Gardan, L. (2000) The taxonomy of Pseudomonas fluorescens and Pseudomonas putida: current status and need for revision. Agronomie 20, 51-63.

Brent K.J., Hollomon D.W. 2007. Fungicide Resistance in Crop Pathogens: How Can it be Managed? Fungicide
Resistance Action Committee, Brussels, Belgium, 56 pp.

Central Insecticides Board \& Registration Committee, Ministry of Agriculture, 2008 (www.cibrc.nic.in,2008)

Chakoosari M.M.D. (2013). Efficacy of various biological and microbial insecticides. Journal of Biology and today's world, 2(5):249-254.

Chet, I., Inbar, J. and Hadar, I. (1997). Fungal antagonists and mycoparasites. In: Wicklow DT, Soderstrom B (eds). The Mycota IV: Environmental and microbial relationships. SpringerVerlag, Berlin. pp.165-184.

Davies T.G., Field L.M., Usherwood P.N., Williamson M.S. (2007). DDT, pyrethrins, pyrethroids and insect sodium channels. IUBMB Life 59 (3): 151-162.

Environmental Microbiology \& Biotechnology, Central University of Punjab, Bathinda (Source)

Fuxa, J. R., Ann. Rev. Entomol. 32 (1987) 225.

Georgis, R. and R. Gaugler. 1991. Predictability in biological control using entomopathogenic nematodes. Journal of Economic Entomology 84: 713-20.

Grewal, P.S., R.U. Ehlers and Shapiro-Ilan, D.I. (eds.). 2005a. Nematodes as biocontrol agents. CABI Publishing, CAB International, Wallingford, Oxfordshire, UK. 505pp.

Harper, J. D., Crop Protection 6 (1987) 117.

Hynes, R. K., and Boyetchko, S. M. (2006). Research initiatives in the art and science of biopesticide formulations. Soil Biology and Biochemistry, 38(4), 845-849.

Kabaluk, T. and Gazdik, K. 2005. Directory of microbial pesticides for agricultural crops nOECD countries. Agriculture and Agri-Food Canada. Accessed June 22, 2012. 
Kurstak, E. (Ed.), Microbial and Viral Pesticides, (1982) Marcel Dekker, New York, 724.

Lacey, L.A. and Undeeen, A.H. Ann. Rev. Entomol. 31(1986) 265.

McCoy, C. W. (Ed.), Microbial Agents for use in Integrated Pest Management Systems. Southern Cooperative Series Bulletin 318. Southern Regional Project S-315: Entomopathogens for use in Pest Management Systems (1987).

Pal, K. K. and B. McSpadden Gardener, 2006. Biological Control of Plant Pathogens. The Plant Health Instructor DOI: 10.1094/PHI-A-2006-1117-02.

Qasem, J.R. (1992). Suggested strategy for weed control. The First Arab Symposium for Weed Control in Orchards and Vegetable Fields. Federation of the Arab Scientific Research Councils. 11-13 October, 1992. Amman-Jordan.

Qasem, J.R. (2003). Weeds and their Control. University of Jordan Publications. Amman, Jordan. 628pp.

Weinzeirl, R., T. Henn, P. G. Koehler and C. L. Tucker, Microbial insecticides, University of Florida, IFAS Extension, (2005) June, 1.

Raaijmakers, J.M., Vlami, M. and de Souza, J.T. Antibiotic production by bacterial biocontrol agents. Antonie Van Leeuwenhoek 81, 537 (2002).

Shetty, P. K., Report on the use and misuse of pesticide in agro-ecosystems in India, National Institute of Advanced Studies, Ban-galore, 2006.

Shetty, P.K., Murugan, M. and Sreeja, K.G. (2008). Crop protection stewardship in India: wanted or unwanted. Curr Sci., 95(4):457-464.

Singh, H.P., Batish, D.R. and Kohli, R.K. (eds.). (2006). Weed Management Handbook. The Haworth Press, USA. $892 \mathrm{pp}$.

Thungrabeab, M. and Aemprapa, S. 2007 Screening of Entomopathogenic Fungi Beauveriae. Spp. against the Aphid, Myzus persicae and Macrosiphum euphorbiae. Proceeding 3rd International Conference on Biopesticides, Kuala Lumpur, Malaysia, pp. 157-160.

Woodring, L. and H.K. Kaya, Steinernmematid and Heterohabditid Nematodes: A Handbook of Techniques. Southern Cooperative Series Bulletin 331. Southern Regional Project S-315: Entomopathogens for use in Pest-Management Systems (1988) Arkansas Agricultural Experiment Station, Fayetteville, 30.

\section{How to cite this article:}

Lovepreet Singh and Vipul Kumar. 2021. Need of Biopesticides Triumph over Chemical pesticides. Int.J.Curr.Microbiol.App.Sci. 10(01): 93-101. doi: https://doi.org/10.20546/ijcmas.2021.1001.011 